\title{
THE EFFECT OF PROJECT BASED LEARNING MODEL AND COOPERATION SKILLS ON RESULTS OF SOCIOLOGY LEARNING IN SMA 4 AMBON
}

\author{
Arnold Sahalessy, J.L. Kundre, Ferdinanda S. Noya \\ Department of Education, Faculty of Teacher Training and Education, \\ Pattimura University - Ambon
}

\begin{abstract}
This study aims to determine (1) the application of the project based learning model in PUBLIC SENIOR HIGH SCHOOL 4 Ambon, (2) the application of cooperation skills in Public Senior High School 4 Ambon, (3) the results of sociology learning in Public Senior High School 4 Ambon, (4) the effect of the application of the learning model project based on learning in Public Senior High School 4 Ambon, (5) the effect of applying cooperative skills in Public Senior High School 4 Ambon, (6) the effect of applying the project based learning model of learning and collaborative skills together on the results of learning sociology at Public Senior High School 4 Ambon. This study used a quasi-experimental research design. The research subjects in this study were 60 students in grade XI IIS. The results of this study indicate that (1) there are significant differences in sociology learning outcomes between groups of students taught with project based learning models and think pair share learning models, (2) there are significant differences in sociology learning outcomes between students who have high and low cooperation skills (3) high and low cooperation skills show no interaction with sociology learning outcomes, (4) Learning model (Project Based Learning and Think-Pair-Share) with cooperation skills show significant interactions with sociology learning outcomes
\end{abstract}

Keywords: Project Based Learning, Cooperation Skills, Learning Outcomes

\section{Introduction}

Development really needs quality human resources. Quality human resources are only obtained through education and training. Government efforts to improve the quality of human resources, one of which is the implementation of the 2013 curriculum. Students are required to think more creatively, innovatively, quickly and responsively to change, and in addition in the 2013 curriculum students are trained to foster courage in themselves. Students will be trained in the ability to logic in solving a problem. The results of the 2013 curriculum will be an increase and balance between the ability to be good human beings (soft skills) and humans who have the skills and knowledge to live properly (hard skills) of students which include competency aspects of attitudes, skills and knowledge.

In the 2013 curriculum used a scientific approach. Strengthening the scientific approach to learning needs to be applied to discovery / research-based learning (discovery / inquiry learning). To encourage the ability of students to produce contextual work, both individually and in groups it is strongly recommended learning by using innovative learning models. There are two innovative learning models that were studied in this study are the "Project Based Learning and Think Pair Share" learning model.

According to Wena (2009) Project Based Learning is one of the innovative learning models, which has many advantages, Project Based Learning is able to increase students' 
learning motivation, increase student activity, improve student skills, develop and practice communication skills in cooperative work groups, giving students the opportunity to organize projects. It is hoped that students will be able to deepen the material and be able to apply the material being studied. Furthermore according to Trianto (2010: 81) "think pair share (TPS)" or thinking in pairs at sharing is a type of cooperative learning that is designed to influence student interaction ".

Student activeness become a very important element in determining learning success (Degeng, 2001). So, more learning is determined by the existence of individual initiative. Individual learners discover and construct knowledge, learning as the preparation of concrete knowledge and experiences, cooperation and reflective activities (Degeng, 2000). Involvement of students in groups, and working together in synergy in groups is needed especially in educational institutions, industrial fields, and government institutions (Carol, 1988; Imel, 1989; and Kerka, 1990).

Every effort made in learning aims to improve student learning outcomes. Learning outcomes are changes in behavior obtained by students after experiencing learning activities (Anni 2005). Muchtar (1991) states that social studies learning does not stimulate students to be actively involved in learning. Muchtar further said that the social studies teaching and learning process carried out by sociology teachers have not been able to foster a culture of learning among students which in turn will affect the acquisition of student learning outcomes.

Based on the background of the problem above, we interested to examine it with the title: The Effect of Learning Models (Project Based Learning and Think Pair Share), and Cooperation Skills on Sociology Learning Outcomes in grade XI of Public Senior High School 4 Ambon.

\section{Research methodology}

This study uses a quasi-experimental research design, with a pretest-posttest nonequivalent control group design model (Wiersma, 1995: 139, Tuckman 1999). This quasiexperimental research design uses students in class (intact group). This research was conducted in Public Senior High School 4 Ambon, lasted for one month, starting from September 2019-October 2019. The subjects of this study were students of grade XI Public Senior High School 4 Ambon. The study requires two classes: grade XI IIS-2 set as an experimental class with the application of the project based learning model, and grade XI IIS-1 set as a control class by applying the think pair share learning model. Each class both the experimental class and the control class involved 30 students.

This research is grouped into two types are (1) initial and final test instruments to measure sociology learning outcomes, and (2) observation sheets to measure students' cooperation skills. A good tool or instrument must meet two conditions are validity and reliability. In conducting data collection steps are taken: 1) preliminary tests, 2) conducting $2 \mathrm{x}$ face-to-face treatment, 3 ) observations from three observers about students' cooperation skills, 4) implementing post-tests.

Data collected were analyzed using analytical techniques: 1) descriptive analysis to describe cooperation skills and sociology learning outcomes, and 2) inferential statistics: analysis of covariance (ANCOVA) to determine the effect of independent and moderator variables on the dependent variable and multiple regression analysis to find out the relationship between cooperation skills and learning outcomes. Hypothesis testing is done by using a significance level of $5 \%$ or $\alpha=0.05$.

\section{Results}

Received April 13 $3^{\text {rd }} 2020$, Revision May 12 ${ }^{\text {th }} 2020$, Accepted for publication June $18^{\text {th }} 2020$.

Copyright (C) 2020 Published by FKIP - Unpatti, ISSN 2721-3110 


\section{a. Description of Research Data}

a) Description of Research Subjects

As explained in the previous chapter, research subjects were taken from Public Senior High School 4 Ambon, which were taken in two classes: grade XI IIS 1 and XI IIS 2. All students in both classes routinely participated in learning activities. So that the students studied were as many as 60 student. The sample in this study were two classes with a total number of 60 students, each class was taken 30 students. Grade XI IIS-1 was given an experiment with a Project Based Learning (PPA) learning model, while grade XI IIS 2 was a control group with Think Pair Share (TPS) learning model.

b) Description of Pre-Test and Post-Test Research Results Data

Student of sociology learning outcomes are measured using a test of learning outcomes. This initial test is in the form of questions taken from the subject matter to be delivered. The following is a description of the pre-test data of sociology learning outcomes in each class or group.

Table Description Data Pre-Test Sociology Learning Outcomes

\begin{tabular}{ccccccc}
\hline $\begin{array}{c}\text { Learning } \\
\text { Model }\end{array}$ & Skill & Mean & N & SD & Min & Max \\
\hline \multirow{2}{*}{ PJBL } & High & 71.67 & 6 & 4.082 & 70 & 80 \\
& Low & 53.75 & 24 & 7.109 & 40 & 60 \\
\hline \multirow{2}{*}{ TPS } & High & 72.50 & 4 & 5.000 & 70 & 80 \\
& Low & 51.54 & 26 & 7.317 & 40 & 60 \\
\hline
\end{tabular}

Based on the table above, it can be explained that in the experimental group (PJBL), the number of students included in the low cooperation skills group was 24 people. The average pre-test score in the group was 53.75 , the minimum value was 40 , and the maximum was 60 . While the number of students with high skills was 6 people. The average pre-test score in this group was 71.67, a minimum score of 70 and a maximum of 80 . In the control group (TPS), the number of students included in the low cooperation skills group was 26 people. The average pre-test score in the group was 51.54, the minimum score was 40 , and the maximum was 60 . While the number of students with high skills was 4 people. The average pre-test score in this group was 72.50 , a minimum score of 70 and a maximum of 80 .

Table Description Post-Test Data Learning Outcomes of Sociology

\begin{tabular}{ccccccc}
\hline $\begin{array}{c}\text { Learning } \\
\text { Model }\end{array}$ & Skill & Mean & N & SD & Min & Max \\
\hline \multirow{2}{*}{ PJBL } & High & 84.42 & 26 & 4.760 & 80 & 95 \\
& Low & 67.50 & 4 & 5.000 & 60 & 70 \\
\hline \multirow{2}{*}{ TPS } & High & 81.43 & 14 & 3.631 & 80 & 90 \\
& Low & 68.13 & 16 & 4.031 & 60 & 70 \\
\hline
\end{tabular}

Based on the table above, it can be seen that in the experimental group (PJBL), the number of students included in the high skills group was 26 people. The average post-test score in the group was 84.42 , the minimum score was 80 and the maximum was 95 . Students included in the low skills group were 4 people. The average post-test score in the group was 67.50 , the minimum value was 80 and the maximum was 90 . While the control group (TPS), the number of students included in the low cooperation skills group was 16 people. The average post-test score in the group was 68.13 , the minimum score was 60 , 
and the maximum was 70. While the number of students with high skills was 14 people. The average post-test score in this group was 68.13 , the minimum value was 60 and the maximum was 70 .

c) Description of the Cooperation Skills Data

The following is a description of the students' cooperation skills scores.

Table Description of Student Skills Cooperation Data

\begin{tabular}{ccccccc}
\hline & \multicolumn{6}{c}{ Scale Statistics } \\
\cline { 2 - 7 } Variable & Mean & Median & Variance & $\begin{array}{c}\text { Std. } \\
\text { Deviation }\end{array}$ & Min & Max \\
\hline Cooperation skill & 66.03 & 65.00 & 55.030 & 3.917 & 55 & 71 \\
\hline
\end{tabular}

Based on the data table above it is explained that the score of students' cooperation skills ranges from 55 to 71 with an average value of 66.03, a median of 65.00 . So, the grouping of students based on the score of cooperation skills that can be formed is if the student has a score value below 65.00, then the students are included in the category of low cooperation skills students. Conversely, if the score of the cooperation skills of the students is equal to or greater than 65.00 , then the students are included in the category of high cooperation skills students. The following description of the results of grouping students based on cooperation skills

Table Description Grouping Cooperation Skills

\begin{tabular}{ccc}
\hline Cooperation skill & Frequency & Percent \\
\hline High & 37 & 61.7 \\
Low & 23 & 38.3 \\
\hline Total & $\mathbf{6 0}$ & $\mathbf{1 0 0}$ \\
\hline
\end{tabular}

Based on the table above it can be explained that students included in the category of low cooperation skills were 23 people (38.3\%). While students included in the category of high cooperation skills amounted to 37 people $(61.7 \%)$.

\section{b. Testing Assumptions of Normality and Homogeneity of Research Data}

Before testing the hypothesis using ANCOVA, testing the assumptions underlying ANCOVA is done first. The assumptions tested are assumptions of normality and homogeneity of variances. The normality assumption was tested using the KolmogorovSmirnov test, while the assumption of homogeneity assumptions was performed using the Levene test at an error level of 5\% $(\alpha=0.05)$. Testing these two assumptions using SPSS 25 software.

a) Testing for Normality Assumptions

Testing the assumption of normality is done using the Kolmogorov-Smirnov test. The assumption of normality is said to be fulfilled if from the test the significance value is greater than 0.05 . Conversely, if the significance value of the results is less than 0.05 , then the assumption of normality is not fulfilled. Regarding the normality test can be seen in appendix 14. Following the results of testing the assumption of normality using SPSS 25 software. 
Normality Assumption Testing Table

\begin{tabular}{ccc}
\hline $\begin{array}{c}\text { Coefficient of Kolmogrov- } \\
\text { Smirnov }\end{array}$ & Significance & Explained \\
\hline 0,181 & 0,014 & Normality distribution \\
\hline
\end{tabular}

Based on table 4.7 above, Kolmogorov-Smirnov coefficient is 0.181 with a significance of 0.014. If the significance value is compared with $\alpha=0.05$, it can be ascertained that the significance value is greater than $\alpha=0.05(0.014>0.05)$. So from this test it can be concluded that the assumption of normality can be made using

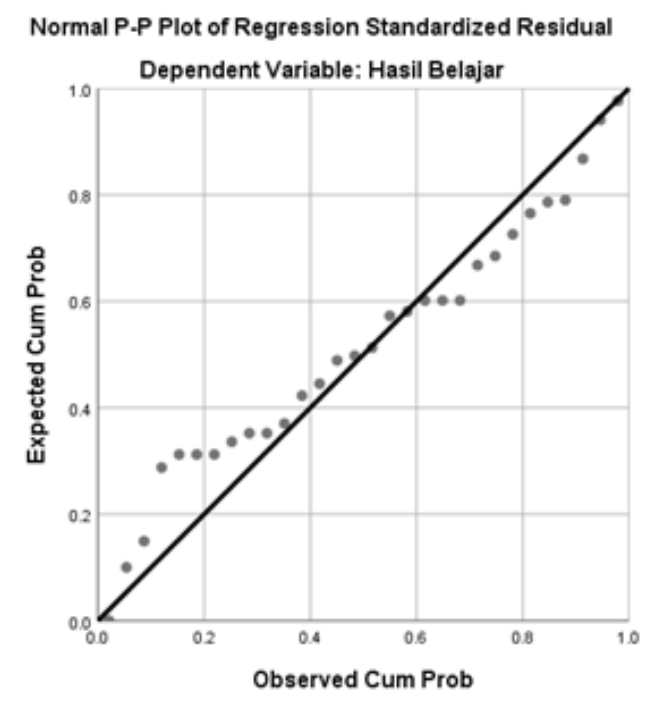

P-P plot. Following P-P plot the results of normality testing.

Figure P-P Graph Plot Testing Normality Assumptions

Based on the picture above, it can be explained that the data distribution is around a straight line. This indicates that the research data analyzed are close to normal distribution or normality is met.

b) Testing the Assumption of Variety Homogeneity

Testing the assumption of homogeneity of variances is done using the Levene test. The assumption of homogeneity of variance is said to be fulfilled if from the test results obtained significance values of more than $\alpha=0.05$. Conversely, if the significance value of the test results is less than 0.05 , then the assumption of homogeneity of variance is not fulfilled. Following are the results of testing the assumption of homogeneity of variances by using SPSS 25 software.

Testing Table Assumptions of Variety Homogeneity

\begin{tabular}{ccc}
\hline Levene Statistic & Significance & Explained \\
\hline 1.244 & 0,330 & Homogeneity \\
\hline
\end{tabular}

Based on the table above obtained the Statistical Levene coefficient of 1,244 with a significance value of 0,330 . If the significance value is compared with $\alpha=0.05$, then it can be ascertained that the significance value is greater than $\alpha=0.05(0,330>0,05)$. So from 
this test it can be concluded that the assumption of homogeneity of variety has been fulfilled.

\section{c. Research Hypothesis Testing}

Based on the analysis using SPSS 25 software, the following analysis results are obtained:

1) Testing the Difference between Sociology Learning Outcomes between Project Based Learning Model and Think Pair Share Learning Model.

To find out the difference between sociology learning outcomes between Project Based Learning models and Think Pair Share, the following table is given:

\section{T-Test Difference Test Results Table}

\begin{tabular}{cccc}
\hline \multirow{3}{*}{ PJBL-TPS } & \multicolumn{3}{c}{ Independent Samples Test } \\
\cline { 2 - 4 } & $\mathbf{T}$ & Dif. & Sig \\
\cline { 2 - 4 } & 3.980 & 58 & 0,000 \\
\hline
\end{tabular}

Based on Table 4.9 above, it can be explained that the results of the $t$ test were 3,980 with a significance of $0,000(\mathrm{P}<0.05)$. This shows that there are significant differences in sociology learning outcomes between groups of students being taught with the project based learning model and the think pair share learning model.

2) Testing the Difference between Sociology Learning Outcomes between High and Low Cooperation Skills

To find out the difference between sociology learning outcomes between Project Based Learning models and Think Pair Share, the following table is given:

\section{T-Test Difference Test Results Table}

\begin{tabular}{cccc}
\hline \multirow{3}{*}{ PJBL-TPS } & \multicolumn{3}{c}{ Independent Samples Test } \\
\cline { 2 - 4 } & $\mathbf{T}$ & Dif. & Sig \\
\cline { 2 - 4 } & 16.051 & 58 & 0,000 \\
\hline
\end{tabular}

Based on the above table, it can be explained that the results of the t test were 16,051 with a significance of $0,000(\mathrm{P}<0.05)$. This shows that there are significant differences in sociology learning outcomes between students who have high and low cooperation skills.

3) Testing of Interaction between Cooperation Skills and Sociology Learning Outcomes

After assuming the normality and homogeneity of the variants underlying ANCOVA, the next step is to analyze ANCOVA data. ANCOVA is used to determine the effect of learning models (project based learning and think pair share), and cooperation skills on sociology learning outcomes.

Table of Result analysis by ANCOVA 


\begin{tabular}{cccccccc}
\hline $\begin{array}{c}\text { Diversity } \\
\text { source }\end{array}$ & Quadrat & Db & $\begin{array}{c}\text { Mean } \\
\text { Quadrat }\end{array}$ & $\begin{array}{c}\text { F- } \\
\text { count }\end{array}$ & $\begin{array}{c}\text { F-table } \\
(\mathbf{5 \% )}\end{array}$ & Sig. & Explained \\
\hline $\begin{array}{c}\text { High } \\
\text { cooperation } *\end{array}$ & & & & & & & \\
$\begin{array}{c}\text { Low } \\
\text { cooperation }\end{array}$ & 20.676 & 1 & 20.676 & 0,447 & 4,01 & 2 & $\begin{array}{c}\text { No } \\
\text { significant }\end{array}$ \\
\hline
\end{tabular}

Based on the results of the analysis using ANCOVA, the source of the diversity of learning model interactions with cooperation skills, obtained an F-count value of 0.447 with a significance value of 0.512 . At the error level of 5\%, an F-table of 4.01 was obtained. If the F-count value is compared with the F-table, then the F-count obtained is less than the F-table $(0.447<4.01)$ and the significance value is greater than $\alpha=0.05$. So from this test it can be concluded that there is no interaction effect of cooperation skills on sociology learning outcomes. To find out the differences in sociology learning outcomes further, descriptive tables are given as follows:

\section{Table Descriptions of Interaction between High and Low Cooperation Skills on Sociology Learning Outcomes}

\begin{tabular}{cccccc}
\hline Skill & Mean & \multicolumn{1}{l}{ N } & \multicolumn{1}{c}{ SD } & Minimum & Maximum \\
\hline low & 46.41 & 22 & 7.475 & 35 & 60 \\
high & 67.08 & 38 & 2.123 & 65 & 71 \\
\hline
\end{tabular}

Based on the descriptive table above, it can be explained that the average sociology learning outcomes of students who have high cooperation skills are higher than those students who have low cooperation skills. So, from this test it can be concluded that the results of learning sociology of students who have high cooperation skills are better than students who have low cooperation skills and there is sufficient empirical evidence to accept the hypothesis that there are differences in sociology learning outcomes between students who have high and low skills.

4) Testing of Interaction of Learning Models (Project Based Learning and Think-PairShare) With Cooperation Skills Against Sociological Learning Outcomes.

After assuming the normality and homogeneity of the variants underlying ANCOVA, the next step is the analysis of ANCOVA data. ANCOVA is used to determine the effect of learning models (project based learning and think pair share), and cooperation skills on sociology learning outcomes.

Table of Results analysis with ANCOVA

\begin{tabular}{cccccccc}
\hline $\begin{array}{c}\text { Diversity } \\
\text { Source }\end{array}$ & Quadrat & Db & $\begin{array}{c}\text { Mean } \\
\text { quadrat }\end{array}$ & F-count & $\begin{array}{c}\text { F-table } \\
(\mathbf{5 \% )}\end{array}$ & Sig. & explained \\
\hline $\begin{array}{c}\text { Interaction } \\
\text { Model }\end{array}$ & & & & & & & \\
Skill & 2574.804 & 1 & 2574.804 & 1590.699 & 4,01 & 0,000 & Significant \\
\hline
\end{tabular}

Based on the results of the analysis using ANCOVA, at the source of the diversity of interaction between learning models and cooperation skills, an F-calculated value of 1590,699 with a significance value of 0,000 was obtained. At the error level of 5\%, an Ftable of 4.01 was obtained. If the F-count value is compared to the F-table, then the F-count 
obtained is greater than the F-table $(1590,699>4.01)$ and the significance value is less than $\alpha=0.05$. So from this test it can be concluded that there is a significant interaction between learning models (Project Based Learning and Think-Pair-Share) with cooperative skills towards sociology learning outcomes. To find out further differences in sociology learning outcomes, a descriptive table is given as follows:

Table Description of Student Learning Outcomes Based on the Interaction of Learning Models and Cooperation Skills

\begin{tabular}{lllllll}
\hline $\begin{array}{l}\text { Learning } \\
\text { Model }\end{array}$ & Skill & Mean & N & SD & Minimum & Maximum \\
\hline PJBL & low & 81 & 5 & 2.236 & 80 & 85 \\
& high & 80.80 & 25 & 7.455 & 60 & 95 \\
\hline TPS & low & 73.53 & 17 & 7859 & 60 & 90 \\
& high & 71.54 & 13 & 6.887 & 60 & 80 \\
\hline
\end{tabular}

Based on the descriptive table above, it can be explained that the average results of sociology of students who are given Project Based Learning treatment and have high cooperation skills are higher than students in other groups and there is sufficient empirical evidence to accept the hypothesis that there is a significant interaction between learning model (project based learning and think-pair-share) with cooperative skills towards learning outcomes of sociology in grade XI Public Senior High School 4 Ambon.

\section{Discussion}

There are significant differences in sociology learning outcomes between groups of students being taught with the project based learning model and the think pair share learning model. This can be seen from the high average learning outcomes of students who learn using the project-based learning model (PPA) compared to the average learning outcomes of students who learn with the Think Pair Share learning model (TPS). The results of this study are in line with research conducted by Suryawan, Santyasa and Gunadi (2019) finding that physics learning achievement among students learning with PBL models (problem based learning) is higher than students learning with other models.

There are significant differences in sociology learning outcomes between students who have high and low cooperation skills. The results of this study are in line with the results of the study by Pratiwi et al, (2018), who found that there were significant differences between the control class and the experimental class in increasing the ability to cooperate. It also has a positive impact on improving social studies learning outcomes for fourth grade students at SD Muhammadiyah Kudus. There is no interaction effect of cooperation skills on sociology learning outcomes. That is, sociology learning outcomes of students who have high and low cooperation skills learning models used in this study, the results are not different. This shows that after following the learning of students who have high cooperation skills and low cooperation skills do not differ learning outcomes.

The results of the data analysis show that there is a significant interaction between the learning model (Project Based Learning and Think-Pair-Share) with the skills of cooperation towards sociology learning outcomes. That is, the learning model (Project Based Learning and Think-Pair-Share) can be applied to students who have high and low skills. Thus the Project Based Learning model is effective to be widely applied in relation to efforts to improve sociology learning outcomes. The results of this study are in line with the results of Sucipto (2017) research that with the project based learning model students can fully participate in learning, because this model is required in order to construct their 
knowledge. Each group member has their respective responsibilities in carrying out project tasks, so that no one is considered to be hitching a ride with the other members. In this study students were trained to work with other friends. In PPA learning, students are given the opportunity to read, research, observe, connect and develop as much knowledge as possible from various sources to enrich their knowledge.

\section{Conclusions and Suggestions}

a. Conclusions

Based on the results of the analysis and discussion that have been put forward as follows: (1) There are significant differences in sociology learning outcomes between groups of students taught with the project based learning model and think pair share learning models, (2) there are significant differences in sociology learning outcomes between students who have high and low cooperation skills, (3) high and low cooperation skills show there is no interaction with sociology learning outcomes, (4) Learning model (Project Based Learning and Think-Pair-Share) with cooperation skills shows there is interaction which is significant towards sociology learning outcomes.

b. Suggestions

Based on the conclusions above, suggestions can be made as follows:

1. PjBL learning model can be an alternative for that PBJL learning model needs to be considered and applied to sociology subjects with other material.

2. The project based learning $(\mathrm{PjBL})$ learning model requires a relatively long time so there is a need for careful learning planning.

3. The results of this study are still limited to the scope of Ambon City, so it is hoped that in the future research will need to be carried out involving larger subjects.

\section{REFFERENCES}

Anni, C.T. 2005. Psikologi Belajar. Semarang : UN Semarang Press

Degeng, I.N.S. 2001 Pokok Pikiran Revolusi Belajar dan Pembelajaran. Penumbuhan Kunci Keunggulan SDM di Era Keserawutan Global. Makalah Seminar Malang:LP3. UM. Departemen Pendidikan Nasional. Dirjend. Pendidikan Dasar dan Menengah.

Made Wena. 2009. Strategi Pembelajaran Inovastif Kontemporer. Jakarta : Bumi Aksar

Sucipto, H. 2017. Penerapan Model Project Based Learning untuk Meningkatkan Minat dan Hasil Belajar IPS. Jurnal Pendidikan: Riset \& Konseptual, .1 (1): 77 - 86

Suryawan, I Made Yuda, I Wayan Santyasa \& I Gede Aris Gunadi. 2019. "Keefektifan Model Problem Based Learning dan Motivasi Berprestasi Siswa dalam Pencapaian Prestasi Belajar Fisika" in MIMBAR PENDIDIKAN: Jurnal Indonesia untuk Kajian Pendidikan, Volume 4(1), Maret, pp.35-54. Bandung, Indonesia: UPI [Indonesia University of Education]. Tersedia online di : http://ejournal.upi.edu/index.php/mimbardik (diakses di Ambon, Indonesia: 14 November 2019).

Trianto. 2010. Desain Model Pembelajaran Inovatif Progresif. Jakarta: Kencana Prenada Media Grup 
Pratiwi, I.A., Ardianti, S.D., dan Kanzunnudin, Moh. 2018. Peningkatan Kemampuan Kerjasama Melalui Model Project Based Learning (Pjbl) Berbantuan Metode Edutainment Pada Mata Pelajaran Ilmu Pengetahuan Sosial. Jurnal Refleksi Edukatika 8 (2). http://jurnal.umk.ac.id/index.php/RE 